\section{Trustworthiness: What Are We Teaching?}

\section{Esther Grassian}

Correspondence concerning this column should be addressed to Esther Grassian and Sarah LeMire, e-mail: esthergrassian@gmail.com and slemire@umich.edu.
What does trustworthiness mean? Can you think of an important part of your life that does not involve trust of some kind, personal or professional? Trustworthiness touches all of us in our personal and professional lives, from individual relationships to leadership and publication at all levels, including government, science, medicine, and history. The column below explores the topic of teaching about trustworthy information by analyzing results of a survey, and it offers some advice for the future.

Love all, trust a few. Do wrong to none.

-William Shakespeare (1564-1616),

All's Well That Ends Well, act 1, scene 1

I

s the concept of trustworthiness new? The Oxford English Dictionary dates the first use of trust in English to 1225 and trustworthiness to $1662 .{ }^{1}$ Trustworthiness takes many forms, as does proof of whether or not something or someone deserves our trust. We license, certificate, credential, elect, and grant degrees to people who meet specified criteria, some more rigorous than others. As methods of communication have expanded, we have seen an enormous increase in first-hand reports (textual and visual) and opinions (signed and anonymous) in addition to more traditional reporting and documentation. We highly value trustworthiness in people, in government, ${ }^{2}$ and in "objects," virtual and physical. Yet, a recent Pew study found that trust in government declined from a high of 72 percent in 1990 to a low of 36 percent in 2016. Between 1973 and 2016, trust in the Supreme Court declined from 45 percent to 36 percent, trust in public schools declined from 58 percent to 30 percent, and trust in "media" (newspapers and television news) declined from a combined 39 percent to 21 percent for newspapers and 20 percent for television news. These Pew survey results indicate a steep decline in trust in various entities for a range of 64 to 80 percent of respondents. ${ }^{3}$

So, what do they trust, and where do librarians fit in this realm of increasingly strongly held opposing views, now that those views can be broadcast widely, with or without supporting, verifiable evidence? We currently read and hear much discussion of "fake news" among the general public, as well as among journalists, scholars, and researchers. ${ }^{4}$ Some ask quite rightly if it is fake news or just news one does not agree with or does not like. Librarians have been helping people learn to think critically about information and its sources for many decades, and welcome this raised consciousness. A March 2017 Strategic Library article points out that for academic libraries, the current situation represents 
"an opportunity and responsibility for librarians to assume a leadership role as trained information professionals in providing relevant information literacy instruction to students and to develop ... collaborative partnerships with the teaching faculty across the disciplines." The author goes on to say that "public and special librarians assume the same role in their communities and organizations respectively. ... While satirical and inaccurate news have always existed ... the use and discussion of fake news has put the need for information literacy skills for all_and for the librarians educated and trained to provide this important education-in the spotlight." Indeed, public libraries increasingly offer seminars, classes, and workshops related to the issue of fake news. ${ }^{6}$

A Google Forms survey was posted to a number of Listservs from July 3 to August 3, 2017, as well as a RUSA weekly e-mail. The survey aimed to determine what librarians in all types of libraries are teaching about trustworthy information, how they assess the effectiveness of this instruction, and which tips and techniques work well for this type of instruction. The data was exported to an Excel spreadsheet and analyzed by the author of this column, who created a separate document listing the teaching tips and techniques suggested by respondents and another document listing the websites utilized by the respondents in teaching. The spreadsheet and supplementary documents are available on the RUSQ website: https://journals.ala.org/index.php/rusq/ article/view/6598.

The survey drew eighty-one responses, largely from academic librarians, but also from public librarians and a few school and special librarians. Close to half of the total number of respondents (thirty-nine, or 48 percent) indicated they have been helping people learn about trustworthy information for ten or more years, with almost another third (twenty-four, or 30 percent) doing so for four to nine years. Following are some collated and individual examples of responses to this survey.

\section{RESPONDENTS}

Academic libraries made up the majority of survey respondents' institutions, at sixty-four respondents (79 percent), with thirteen respondents from public libraries (16 percent), and just two respondents each from school libraries (2 percent) and special libraries (2 percent). See table 1 .

These figures may reflect the fact that librarians in academic libraries have been helping students, staff, and faculty learn about trustworthy information for many decades, while public libraries have entered this arena of teaching and learning more recently.

\section{NEEDS ASSESSMENT}

How do librarians decide what to teach, particularly in relation to trustworthy information? Many survey respondents
Table 1. Respondents: Types of Libraries

\begin{tabular}{lcc}
\hline Type of Library & $\begin{array}{c}\text { No. of } \\
\text { Respondents }\end{array}$ & $\begin{array}{c}\text { \% of Total } \\
\text { Respondents }\end{array}$ \\
Academic Libraries & 64 & 79 \\
Two-Year Colleges & 19 & 23 \\
Four-Year Colleges & 21 & 26 \\
Research Universities & 24 & 30 \\
Public Libraries & 13 & 16 \\
School Libraries & 2 & 2 \\
Special Libraries & 2 & 2 \\
\hline
\end{tabular}

who help people learn about trustworthy information rely on reactive forms of needs assessment to determine what their users would like to learn. These types of needs assessment include:

- reference queries: 45 (56 percent)

- informal outreach: 45 (56 percent)

- user requests: 29 (36 percent)

- teacher/faculty requests: 7 (9 percent)

Some proactively conduct formal needs assessments to find out what their users want to learn (thirteen, or 16 percent). This means they may distribute surveys asking people about their interests in various possible topics that may be addressed through instruction of some kind.

\section{TEACHING CONTENT}

Exactly what do librarians teach regarding trustworthy information? The vast majority of survey respondents across types of libraries help people learn how to evaluate websites (seventy-four, or 91 percent). Sixty-three (78 percent) of total survey respondents help people learn how to evaluate periodical articles, and an almost equal number help people learn how to distinguish among different domains, such as .com, .edu and .gov (sixty-one, or 75 percent). Forty-eight respondents (59 percent) help users learn how to evaluate books, and a much smaller percentage help people learn how to evaluate social media, such as Facebook and Twitter (forty, or 49 percent). A breakdown of these responses by type of library, as indicated in the table below, reveals that research universities and public libraries lead in helping people learn to evaluate social media. For public libraries, "fake news" classes may be an important way they are expanding beyond computer literacy for the general public, given the current interest in this topic. All types of libraries should probably focus more on evaluating social media, given the fact that according to a recent Pew survey, "67\% of Americans ... get at least some of their news on social media-with two-in-ten doing so often." 


\section{INFORMATION LITERACY AND INSTRUCTION}

Table 2. Survey question 4. What do you include in the content of instruction on trustworthiness of information? (Select all that apply.)

\begin{tabular}{|c|c|c|c|c|c|c|c|}
\hline Content & $\begin{array}{l}\text { All Academ- } \\
\text { ic Libraries } \\
(64)\end{array}$ & $\begin{array}{l}\text { Two-Year } \\
\text { Colleges } \\
\text { (19) }\end{array}$ & $\begin{array}{l}\text { Four-Year } \\
\text { Colleges } \\
(21)\end{array}$ & $\begin{array}{c}\text { Research } \\
\text { Universities } \\
\text { (24) }\end{array}$ & $\begin{array}{l}\text { Public } \\
\text { Libraries } \\
\text { (13) }\end{array}$ & $\begin{array}{l}\text { School } \\
\text { Libraries } \\
(2)\end{array}$ & $\begin{array}{l}\text { Special } \\
\text { Libraries } \\
\text { (2) }\end{array}$ \\
\hline Evaluating Websites & $59(92 \%)$ & $18(95 \%)$ & $17(81 \%)$ & $24(100 \%)$ & $11(85 \%)$ & $2(100 \%)$ & $1(50 \%)$ \\
\hline $\begin{array}{l}\text { Evaluating Periodical } \\
\text { (Magazine, Journal, } \\
\text { Newspaper) Articles }\end{array}$ & $53(83 \%)$ & $15(79 \%)$ & $15(71 \%)$ & $24(100 \%)$ & $6(46 \%)$ & $1(50 \%)$ & $1(50 \%)$ \\
\hline $\begin{array}{l}\text { Distinguishing Among } \\
\text { Different Internet Domains } \\
\text { (e.g., .com, .edu, .gov) }\end{array}$ & $49(77 \%)$ & $16(84 \%)$ & $13(62 \%)$ & $20(83 \%)$ & $8(62 \%)$ & $2(100 \%)$ & $1(50 \%)$ \\
\hline Evaluating Books & $43(67 \%)$ & $13(68 \%)$ & $13(62 \%)$ & $17(71 \%)$ & $5(38 \%)$ & 0 & 0 \\
\hline $\begin{array}{l}\text { Evaluating Social Media } \\
\text { (e.g., Facebook, Twitter) }\end{array}$ & $30(47 \%)$ & $9(47 \%)$ & $7(33 \%)$ & $15(63 \%)$ & $7(54 \%)$ & $1(50 \%)$ & $1(50 \%)$ \\
\hline
\end{tabular}

Note: Percentages are of survey respondents from each type of library.

\section{INSTRUCTION METHODS}

In what ways do librarians offer instruction about trustworthy information? Eight-five percent of respondents, a large majority, help people learn about this topic at the reference desk, with another 52 percent helping people learn about it through chat reference. Given the majority of academic library respondents, it is not surprising that many of the total number of respondents help people learn about this topic through "one-shots" (guest sessions) for credit courses (72 percent) and through credit courses taught by librarians (46 percent). Sixty percent offer this kind of help through LibGuides or websites, while 47 percent offer one-time standalone classes or workshops.

Table 3 below provides more detailed information regarding the instructional methods utilized by the respondents. ${ }^{8}$

\section{ASSESSMENT}

More than half of total survey respondents (53 percent) ask learners to complete user satisfaction assessment forms in order to find out about the effectiveness of their instruction, while a smaller number of respondents (thirty-four, or 42 percent) use learning assessment for the same purpose. Although self-reports can be useful in determining attitudes, ${ }^{9}$ they can be notoriously inaccurate in measuring actual learning. ${ }^{10}$ This points to the need for more learning assessment to determine the effectiveness of instruction, at least on a short-term basis. Research may be needed to determine the extent of long-term retention of instruction, as opposed to "vaccination" regarding the ability to determine trustworthy information via a single workshop, class, or one-time guest lecture. However, a number of respondents did report on the effectiveness of their instruction.

\section{MOST EFFECTIVE TEACHING/LEARNING METHODS (FROM ASSESSMENT DATA)}

Almost three-quarters of total survey respondents (sixty, or 74 percent) answered a question regarding which of their instruction methods is most effective, on the basis of their own assessment data results. Of those sixty responses, inperson instruction of various kinds garnered almost half (twenty-nine, or 48 percent). In-person instruction responses consisted of one-shots for credit courses (nineteen, or 32 percent), in-person reference (four, or 7 percent), and other forms of in-person instruction, including programs (six, or 10 percent). Some also responded with credit courses (seven, or 12 percent) and noncredit classes or workshops (two, or 3 percent). Online tutorials, LibGuides, and handouts received just one response each (2 percent). Interestingly, twenty-three of the sixty responses (38 percent) consisted of "N/A" or "don't know" or miscellaneous comments that did not indicate assessment data collection or analysis. These responses indicate that assessment of the effectiveness of all types of instruction needs more attention, as each form of instruction requires time and effort on the part of librarians, as well as other library staff.

\section{TIPS AND TECHNIQUES}

Many respondents generously offered a variety of tips and techniques for helping people learn about trustworthy information. Their advice falls primarily into the categories of active learning, the use of real-world examples, and collaborating with instructors, along with connecting to course or assignment goals. Some representative examples of each of these categories follow. Keep in mind that their effectiveness may vary depending on the age, educational level, interests, and skill level of the audience but that each may be adapted for different audiences in different types of libraries. 
Table 3. Types of Instruction

\begin{tabular}{|c|c|c|c|c|c|c|c|c|}
\hline $\begin{array}{l}\text { Instructional } \\
\text { Method }\end{array}$ & $\begin{array}{c}\text { Total Re- } \\
\text { spondents } \\
(81=100 \%)\end{array}$ & $\begin{array}{c}\text { All } \\
\text { Academic } \\
\text { Libraries } \\
(64=79 \%)\end{array}$ & $\begin{array}{l}\text { Two-Year } \\
\text { Colleges } \\
(19=23 \%)\end{array}$ & $\begin{array}{l}\text { Four-Year } \\
\text { Colleges } \\
(21=26 \%)\end{array}$ & $\begin{array}{c}\text { Research } \\
\text { Universities } \\
(24=30 \%)\end{array}$ & $\begin{array}{c}\text { Public } \\
\text { Libraries } \\
(13=16 \%)\end{array}$ & $\begin{array}{l}\text { School } \\
\text { Libraries } \\
(2=2 \%)\end{array}$ & $\begin{array}{c}\text { Special } \\
\text { Libraries } \\
(2=2 \%)\end{array}$ \\
\hline Reference Desk & 69 (85\%) & $54(67 \%)$ & $17(21 \%)$ & $14(17 \%)$ & $23(28 \%)$ & $12(15 \%)$ & $1(1 \%)$ & $2(2 \%)$ \\
\hline Chat Reference & $42(52 \%)$ & $36(44 \%)$ & $12(15 \%)$ & $10(12 \%)$ & $14(17 \%)$ & $6(7 \%)$ & 0 & 0 \\
\hline Credit Courses & $37(46 \%)$ & $37(46 \%)$ & $12(15 \%)$ & $10(12 \%)$ & $15(19 \%)$ & 0 & 0 & 0 \\
\hline Exhibits & $15(19 \%)$ & $12(15 \%)$ & $4(5 \%)$ & $3(4 \%)$ & $5(6 \%)$ & $2(2 \%)$ & 0 & $1(1 \%)$ \\
\hline Flyers or Posters & $28(35 \%)$ & $25(31 \%)$ & $13(16 \%)$ & $5(6 \%)$ & $7(9 \%)$ & $3(4 \%)$ & 0 & 0 \\
\hline $\begin{array}{l}\text { LibGuides or } \\
\text { Websites }\end{array}$ & $55(68 \%)$ & 49 (60\%) & $13(16 \%)$ & $13(16 \%)$ & $23(28 \%)$ & $5(6 \%)$ & $1(1 \%)$ & 0 \\
\hline $\begin{array}{l}\text { One-Shots for } \\
\text { Credit Courses }\end{array}$ & $62(77 \%)$ & $58(72 \%)$ & $17(21 \%)$ & $18(22 \%)$ & $23(28 \%)$ & $2(2 \%)$ & $1(1 \%)$ & $1(1 \%)$ \\
\hline $\begin{array}{l}\text { One-Time Classes } \\
\text { or Workshops }\end{array}$ & $43(53 \%)$ & $38(47 \%)$ & $13(16 \%)$ & $8(10 \%)$ & $17(21 \%)$ & $5(6 \%)$ & 0 & 0 \\
\hline Online Tutorials & $34(82 \%)$ & $33(41 \%)$ & $9(11 \%)$ & $8(10 \%)$ & $16(20 \%)$ & $1(1 \%)$ & 0 & 0 \\
\hline Online Checklists & $21(26 \%)$ & $21(26 \%)$ & $7(9 \%)$ & $4(5 \%)$ & $10(12 \%)$ & 0 & 0 & \\
\hline $\begin{array}{l}\text { Printed Handouts } \\
\text { or Guides }\end{array}$ & $41(51 \%)$ & $34(42 \%)$ & $13(16 \%)$ & $9(11 \%)$ & $12(15 \%)$ & $6(7 \%)$ & 0 & $1(1 \%)$ \\
\hline Programs & $23(28 \%)$ & $16(20 \%)$ & $3(4 \%)$ & $6(7 \%)$ & $7(9 \%)$ & $6(7 \%)$ & $1(1 \%)$ & 0 \\
\hline $\begin{array}{l}\text { Social Media } \\
\text { Posts }\end{array}$ & $22(27 \%)$ & $18(22 \%)$ & $6(7 \%)$ & $4(5 \%)$ & $8(10 \%)$ & $3(4 \%)$ & 0 & $1(1 \%)$ \\
\hline Videos & $23(28 \%)$ & $22(27 \%)$ & $5(6 \%)$ & $6(7 \%)$ & $11(14 \%)$ & $1(1 \%)$ & 0 & 0 \\
\hline
\end{tabular}

Note: Percentages in the table refer to the total number of respondents: $n=81$.

(See a complete list of tips and techniques suggested by respondents: https://journals.ala.org/index.php/rusq/article/ view/6598.)

\section{Active Learning}

- "Hands-on exercises work best! For my for-credit courses, I like to give the class two websites (one good and one bad), then do a jigsaw by splitting the class up into groups and assign them each a separate evaluative question to ask about the sites. Then the class comes together and presents on what their findings were about each question, and the class votes together on which site would be the most trustworthy. I find that this really helps them feel more confident about choosing sources."

- "I like to have students find examples of good and bad info on their topic before the session and then present it and explain how they determined the info was good or bad."

- "Provide specific examples for students to evaluate on their own and have them explain why they would trust the information."

- "Ask the students questions instead of 'telling them.' For instance, if you ask them what is the difference between Google and Yahoo, they usually have no clue. This helps them to understand they may not know everything about information."
- "Make it a student-centered discussion rather than a lecture."

- "Personal engagement and answering the immediate question work best, but have a good, concise document (like a bookmark or handout) to give out for when the patron/student has more questions."

- "Remember that evaluating sources is a developmental process and checklists can be overwhelming. Tapping into a user's knowledge of rhetorical situations, even if not formally understood, gives them something to hang their hat on."

- "Teach students to recognize passionate words; have students connect source to assignment (seem to get better sources if asked to justify the choice)."

- "Focus on AUTHORSHIP (source of content-slightly different than 'authority') and EVIDENCE (what proof is offered to back up claims in a source, e.g., quotes from experts, personal testimony, summary of outside research, full citations of prior research, methodology of new study, etc.)."

\section{Use of Real-World Examples}

- "I focus on 'fake news' a lot and have tried to emphasize lots of things about it to students, most importantly that there is a difference between 'fake news' and 'news that 
makes a person unhappy'-it seems obvious sometimes, but it's surprising how many students haven't necessarily made that connection."

- "Relate to something that students already do, such as assessing sellers on eBay/Amazon for their reputation (reviews). Stress that they need to do the same level of assessment for information that they will be using for research or in their professional field, using to make or recommend decisions to their boss or team."

- "Use examples drawn for [sic] the reference interview or deal with crime (the user as detective)."

- "Developing context by teaching them about searching in conjunction with evaluation is key; they can't differentiate unless they've seen more reliable sources."

- "Keep it simple and provide concrete examples."

\section{Collaboration with Instructors (Primarily in School and Academic Library Settings)}

- "Faculty buy in, especially with expectations."

- "Collaborate with the instructor of record: learn about the course beforehand and tie [the] session goals to course goals."

\section{WHERE DO WE GO FROM HERE?}

Though in writing the use of the word propaganda dates back to $1822,{ }^{11}$ the topic of trustworthy information now occupies a prominent position in news media and in the minds of many among the general public, much more so than at any other time in recent memory. Fake news and information manipulation shock our sensibilities repeatedly. This is partly due to the fact that many are handicapped by news "silos" and the personalization of "news" perpetuated by social media algorithms that feed news supporting a particular point of view held by the viewer. ${ }^{12}$ For these reasons, some wonder how they can determine whether or not the news and information they encounter is reliable as they try to understand the world around them-especially if it conflicts with news and facts beyond their own silos. On the positive side, however, public consciousness seems higher than ever before regarding the need to fact-check and weigh divergent views.

Given the present circumstances, and the generally short duration of public attention to issues like this, how can we capitalize on the current situation to help people learn how to think critically about information of all kinds? Scholars, faculty, and researchers delve deeply into their broad disciplines and their focused areas of expertise. Librarians, on the other hand, learn about a broad array of information tools and resources for many different disciplines, including who develops them, how they work, how they compare to other information tools and resources, and why they exist. We seek to help people of all ages and educational backgrounds learn this kind of general, broad-based information evaluation: how to pose questions about information and its sources, and how to look for clues to the answers. How can librarians further this process?

As the results of this survey indicate, many librarians have been trying to help people learn about trustworthy information for years, the vast majority (sixty-three, or 78 percent) for anywhere from four to ten or more years. Recently, librarians have developed a number of LibGuides and have offered an increasing number of workshops and classes related to the topic of trustworthy information. However, given the current environment of raised consciousness regarding fake news, librarians in all types of libraries need to expand their teaching and learning to include evaluation of social media, and we need to do more to assess learning as a result of our instruction. How can we do this efficiently and effectively? We can help each other

Regardless of their type of library, some respondents to this survey very importantly suggested reaching out to work with and learn from others in this worthy teaching and learning endeavor. Comments included: "Review LibGuides from other institutions, reach out to other instruction librarians," "Build network of public, school, academic colleagues to educate," and "I need advice on this myself!" This column makes a first attempt to reach out across types of libraries to share and provide ideas, support, and encouragement to those new to teaching about trustworthy information, or those wanting new approaches to helping people of many ages and educational levels learn about trustworthy information-for, in spite of all of the worthy efforts of librarians over the years, information literacy instruction, including teaching about trustworthy information, reaches limited numbers of students and the general public. To expand efforts to meet this dire need for ways to deal with the flood of information-fake and true- a next step could be to formalize outreach efforts regarding instruction across types of libraries through data sharing, instructional observations, and mentoring programs. Let us help each other help all of our communities!

\section{References}

1. Oxford English Dictionary Online, s.v. "trust, n.," accessed October 20, 2017, http://www.oed.com/view/Entry/207004?rs key=GfADyp\&result=1\&isAdvanced=false; Oxford English Dictionary Online, s.v. "trustworthy, adj.," accessed October 20, 2017, http://www.oed.com/view/Entry/207023?redirectedFrom =trustworthiness.

2. Michael Levin, "Social Contract," in Dictionary of the History of Ideas, ed. Phillip P. Wiener, vol. 4, Psychological Ideas, to Zeitgeist (New York: Scribner's, 1973), 251-63. Locke's theory regarding trust in government is based on the idea that "the government should serve to implement the will of the people," based on the idea of "trust," rather than a contract, to ensure that government is subservient to the people (4:258). Rousseau argued for a fairly rigid "social contract"; "its terms allow the body politic absolute power over all its members" (4:259). On the other hand, according to the author of this essay, Paine argued that "the constitution is a [mutual] compact between the people and the government," outlining the limitations of government (4:260).

3. Lee Rainie, "Education in the Age of Fake News and Disputed 
Facts," Pew Research Center, June 15, 2017, http://www.pew internet.org/2017/06/15/education-in-the-age-of-fake-news -and-disputed-facts/.

4. Chris Barr, "20 Projects Will Address the Spread of Misinformation through Knight Prototype Fund," Knight Foundation, June 22, 2017, https://www.knightfoundation.org/articles/20 -projects-will-address-the-spread-of-misinformation-through -knight-prototype-fund.

5. Kathy Stein-Smith, "Librarians, Information Literacy, and Fake News," Strategic Library, no. 37 (March 15, 2017): 4, http://www .libraryspot.net/SL/SL_Marl7_1.pdf.

6. Karen Ann Cullotta, "Arlington Heights Librarians Take on Fake News," Chicago Tribune, January 26, 2017, http://www .chicagotribune.com/suburbs/arlington-heights/news/ct-ahp -arlington-library-fake-news-tl-0202-20170126-story.html; Jerry Large, "Librarians Take Up Arms against Fake News," Seattle Times, February 6, 2017, https://www.seattletimes.com/seattle -news/librarians-take-up-arms-against-fake-news/; Amanda Hoover, "The Fight against Fake News Is Putting Librarians on the Front Line-and They Say They're Ready," Christian Science Monitor, February 15, 2017, https://www.csmonitor.com/The -Culture/2017/0215/The-fight-against-fake-news-is-putting -librarians-on-the-front-line-and-they-say-they-re-ready.

7. Elisa Shearer and Jeffry Gottlieb, "News Use across Social Media Platforms, 2017," Pew Research Center: Journalism and Media, September 7, 2017, http://www.journalism.org/2017/09/07/news -use-across-social-media-platforms-2017/?utm_source=Adap tiveMailer\&utm_medium=email\&utm_campaign=Email\%20 Campaign\%20for\%20Social\%20Media\%20and\%20News\&org= $982 \& l v l=100 \&$ ite $=1678 \& l e a=347325 \& \mathrm{ctr}=0 \&$ par $=1 \&$ trk $=$.

8. In addition to determining instruction methods, this survey aimed to find out which methods libraries offer asynchronously (on your own), as opposed to synchronously (in real time). Due to a flaw in the survey, however, respondents were required to choose either synchronous or asynchronous for each method they selected. Yet, in actuality, some may offer both synchronous and asynchronous use of some of the same methods. For this reason, the table does not indicate synchronous or asynchronous, but simply lists the types of instruction methods utilized.

9. Thomas A. Angelo and K. Patricia Cross, Classroom Assessment Techniques: A Handbook for College Teachers, 2nd ed. (San Francisco: Jossey-Bass Publishers, 1993).

10. Tiaci Sitzmann, Katherine Ely, Kenneth G. Brown, and Krishna N. Bauer, "Self-Assessment of Knowledge: A Cognitive Learning or Affective Measure?" Academy of Management Learning and Education 9, no. 2 (2010): 169-91, https://doi.org/10.5465/AMLE .2010.51428542; Ernesto Panadero, Gavin T. L. Brown, and Jan-Willem Strijbos, "The Future of Student Self-Assessment: A Review of Known Unknowns and Potential Directions," Educational Psychology Review 28, no. 4 (2016): 803-30, https:// doi.org/10.1007/s10648-015-9350-2; Justin Kruger and David Dunning, "Unskilled and Unaware of It: How Difficulties in Recognizing One's Own Incompetence Lead to Inflated Self-Assessments," Journal of Personality and Social Psychology 77, no. 6 (December 1999): 1121-34, https://doi.org/10.1037/0022-3514 .77.6.1121; Daniel Simons, "Unskilled and Optimistic: Overconfident Predictions despite Calibrated Knowledge of Relative Skill," Psychonomic Bulletin and Review 20, no. 3 (June 2013): 601-7, https://doi.org/10.3758/s13423-013-0379-2.

11. The Oxford English Dictionary lists the following as one of the definitions of propaganda: "3. The systematic dissemination of information, esp. in a biased or misleading way, in order to promote a political cause or point of view. Also: information disseminated in this way; the means or media by which such ideas are disseminated. 1822 T. Carlyle Let. 7 Dec. in Coll. Lett. T. \& J. W. Carlyle (1970) II. 224 I think you have done well positively to decline any interference with their propaganda purposes." Oxford English Dictionary Online, s.v., "propaganda, n.," accessed October 20, 2017, http://www.oed.com/view/Entry /152605? rskey=gfdjC0\&result=1\&isAdvanced=false.

12. Lisa Schmeiser, "The Effect of Facebook's Social Media Silo on Itself and You," Observer, May 3, 2017, http://observer.com/2017/05 /facebook-social-media-silo-effect-social-discourse/. 